\title{
APPLICATION OF POWER POINT MEDIA TOWARDS INCREASING LEARNING OUTCOME OF CLASS IV STUDENTS ON THEMATIC LEARNING AT SDN KEMUNING
}

Dian Nur Antika Eky Hastuti

PGRI Madiun University

E-mail: nurantika27@gmail.com

\begin{tabular}{lcl}
\hline ARTICLE INFO & ABSTRACT \\
\hline Received: & This study aims to determine the application of Power Point
\end{tabular}

media to fourth grade students in thematic learning at SDN

Revised:

August, 17 ${ }^{\text {th }} 2021$

Approved:

August, 19th 2021 Kemuning, to determine the improvement of fourth grade student learning outcomes to the application of power point media in thematic learning at SDN Kemuning and to determine the response of fourth grade students to the application of Power point media. Point on thematic learning at SDN Kemuning. This research is a Classroom Action Research (CAR) which was carried out in two cycles. The subjects of the research were the fourth grade elementary school students with 20 students consisting of 10 male students and 10 female students. The results of this study indicate that the application of power point in thematic learning can increase the learning interest of fourth grade students at SDN Kemuning. It is proven that students are more enthusiastic in listening, paying attention and asking researchers. Meanwhile, the learning outcomes of fourth grade students at SDN Kemuning can be seen from the average posttest score and the percentage of complete learning. In the first cycle, 16 students who got a score of 75 with a learning completeness of 90\%. In the second cycle, 18 students who got a score of 75 with a learning completeness of $95 \%$. Student responses to the application of Power Point media in thematic learning indicate that students are happy with the application of this media and through the 


\begin{tabular}{ll}
\hline & $\begin{array}{l}\text { application of this Power Point media students can more } \\
\text { easily understand the material presented by the teacher. }\end{array}$ \\
\hline KEYWORDS & Power Point Media, Learning Outcome, Thematic Learning \\
\hline cc) (i) (2) & This work is licensed under a Creative Commons \\
\hline
\end{tabular}

\section{INTRODUCTION}

Educational institutions are one of the facilities that can provide quality education. To achieve quality education, teaching and learning activities in schools must meet learning components. According to (Djamarah \& Zain, 2006), "As a system of course teaching and learning activities contain several components which include objectives, lesson materials, teaching and learning activities, methods, tools and resources, and evaluation".

One of the biggest problems of education in Indonesia is the low quality of basic education in SD/MI which is very decisive for the continuation of subsequent education (Prastowo, 2014). The 2013 curriculum is an improvement and balance between several competencies, namely attitudes, skills, and knowledge competencies. This is following the mandate of Law no. 20 of 2003 as stated in the explanation of Article 35, namely graduate competence is a graduate's ability qualification which includes attitudes, knowledge, and skills by agreed national standards (Rosyidah, 2015).

Thematic learning is learning that uses themes in linking several subjects so that it can provide meaningful experiences to students (Efendi, 2009). Trianto in (Wahyuni, Setyosari, \& Kuswandi, 2017) states that thematic learning is defined as learning designed based on certain themes, in which the theme is discussed in terms of various subjects.

The digitalization era is a very real effort that will be faced by educational institutions now marked by technological advances on the demand side of quality developments that have taken place so that their achievement in social and cultural changes in the school community is significant (Hermawansyah, 2021).

Learning tools or media are one of the most important components in the teaching and learning process, this is as stated (Djamarah \& Zain, 2006), "In the teaching and learning process the presence of the media has a fairly important meaning. Because in these activities the ambiguity of the material presented can be helped by presenting the media as an intermediary. The complexity of the material to be delivered to students can be simplified with the help of the media. Media can represent what the teacher is unable to say through certain words or sentences. Even the abstraction of the material can be concretized with the presence of the media. Thus, it is easier for students to digest the material than without the media.

The main purpose of learning media is to facilitate the teaching and learning process (Abi Hamid et al., 2020). Learning media that can be used in the teaching and learning process are currently quite numerous and quite varied, depending on the needs and funds provided by educational institutions (Kustiawan, 2016). The world of adult education is entering the era of the media world, where learning activities require the reduction of the lecture method and are replaced by the use of many media, one of which is PowerPoint (Nurseto, 2011). The use of media in the learning process can help the smoothness, effectiveness, and efficiency of learning objectives (Misbahudin, Rochman, Nasrudin, \& Solihati, 2018).

Microsoft Office PowerPoint is an office application program with a slide show 
type (worksheet which is an alternate mirror) that is used to present concepts and arguments that you want to show others (Fandana \& Indrianti, n.d.). PowerPoint is widely used because of its easy operation, and everyone can make PowerPoint (Wanti, n.d.).

Currently, the teachers at SDN Kemuning, especially grade IV in their classroom learning have never used PowerPoint media. Even though the use of PowerPoint as a learning media is very interesting (Bici, 2020). One of the advantages of Microsoft PowerPoint media according to (Suratman, 2009) is that the presentation is attractive because there are games of color, letters, and animation, both animated text and animated images or photos. Because it has these advantages, PowerPoint is a suitable learning media for thematic learning subjects in class IV SDN Kemuning.

The characteristics of fourth-grade students at SDN Kemuning based on the results of initial observations in daily learning tend to be bored in participating in learning. So it has an impact on low learning outcomes. The researcher hopes that the use of PowerPoint media can improve the learning outcomes of fourth-grade students in thematic learning at SDN Kemuning. As stated (Sadiman, Rahardjo, \& Haryono, 2003) that “...the behavior theory (behaviorism theory) taught by B. F. Skinner began to influence the use of media in learning activities. This theory encourages people to pay more attention to the teaching and learning process.

Based on the explanation above, the purpose of this study is to determine the application of PowerPoint media to fourth-grade students in thematic learning at SDN Kemuning, to identify improving the learning outcomes of fourth-graders towards the application of PowerPoint media is thematic learning at SDN Kemuning and to determine the response of fourth-graders to the application of PowerPoint media in thematic learning at SDN Kemuning.

\section{RESEARCH METHODS}

This research is one of the efforts of teachers or practitioners in the form of various activities carried out to improve or improve the quality of class lessons. In this study, the type of classroom action research (Classroom Action Research) was carried out in two cycles. This action was deliberately raised by researchers to improve and improve the quality of learning. While the research approach used is a qualitative approach that aims to get a clear and real picture of the process of applying PowerPoint media to the learning outcomes of Class IV students in Thematic Learning at SDN Kemuning.

Based on the reviews that have been submitted in the introduction, efforts to improve learning are needed so that teaching and learning activities in the classroom are more effective and achieve learning mastery targets. Thus, to improve learning practices and improve teaching and learning activities in the classroom can be completed with the method of classroom action research (Classroom Action Research). The actions taken by the researchers in this study were using PowerPoint media on the learning outcomes of Class IV students in Thematic Learning at SDN Kemuning.

In this study, the presence of researchers in the field is necessary because researchers will act as (1) action planners, (2) action providers, (3) data collectors, (4) data analyzers, and (5) reporting research results. In this study, the researcher was assisted by one person who would document teaching and learning activities in the form of photos.

The instruments used in this study were field notes which were used to monitor student attitudes and the application of PowerPoint media, posttest questions were used to measure the extent to which students' cognitive learning outcomes were achieved after PowerPoint was applied and closed questionnaires were given to fourth-grade students aimed at obtaining data on the responses of fourth-graders to the application of 


\section{Dian Nur Antika Eky Hastuti}

PowerPoint media in Thematic Learning at SDN Kemuning. 
Data analysis is carried out every one cycle ends. The data analyzed are data:

a. Data on student attitudes and the application of PowerPoint media were analyzed descriptively. This measurement is guided by aspects that arise during the learning process based on the field notes that have been made. Then compare the results of observations in cycle I and cycle II so that it will be known whether there is a change in learning conditions between cycle I and cycle II.

b. Learning outcomes data were analyzed after the posttest was completed by students. The results of this posttest will provide students' cognitive aspects of learning outcomes. Then the results of the posttest in the first cycle are compared with the posttest results in the second cycle to determine whether there are changes to the cognitive aspects of students.

c. Data on student responses to the application of PowerPoint media. This measurement is based on the checklist $(\sqrt{ })$ on every aspect that appears during the learning process based on the questionnaire that has been made. Then compare the results of the questionnaire in cycle I and cycle II so that students' responses to the application of PowerPoint media will be known.

\section{RESULTS AND DISCUSSION}

Researchers plan learning using PowerPoint media which is expected to increase student interest in learning so that student learning outcomes will also increase.

A. Teaching and Learning Activities Cycle I

1. Action Planning Stage Cycle I follows:

Prior to the implementation stage in cycle I, several preparations were made as

1) Develop a Learning Implementation Plan (RPP) for cycle I.

2) Prepare relevant books.

3) Arrange thematic learning materials in PowerPoint slides and their animations for cycle I.

4) Arrange posttest questions for cycle I.

5) Compile a field note sheet for the cycle.

6) Prepare a questionnaire to determine student responses to learning by using PowerPoint learning media.

\section{Action Implementation Stage Cycle I}

a. Meeting I

The implementation of learning in cycle I was carried out for $2 \times 45$ minutes (2 hours of lessons) which was divided into two meetings. The installation of media in the classroom is done before the class bell rings. Teaching and learning activities do not begin with introductions because the researcher who will act as the teacher has introduced himself during the initial observation. Teaching and learning activities begin by greeting, praying and attending to students. Then the teacher slightly repeats last week's lesson material for three minutes.

To provide an illustration of today's material, the teacher has started using Microsoft PowerPoint media when the first slide showing the thematic learning material is shown to students for two minutes. In the core learning activity for forty minutes, the teacher explains the thematic learning materials using Microsoft PowerPoint learning media with the lecture method for 40 minutes including asking students questions and answering them again. 


\section{Dian Nur Antika Eky Hastuti}

Based on the data from the field notes for the first cycle of the first meeting, it is known that during the teaching and learning activities the students looked happy and enthusiastic. Although sometimes the classroom atmosphere is crowded and students are still less active, the classroom atmosphere remains conducive so that teaching and learning activities run smoothly and all materials in the Learning Implementation Plan (RPP) have been delivered to students. There is no damage to the media. During teaching and learning activities, student involvement is good and there is good cooperation between teachers and students.

\section{b. Meeting II}

The second meeting in cycle 1 was used to provide a posttest of thematic learning materials. In this posttest, each student gets one question and one answer sheet that is done independently and is not allowed to cooperate in any form. Posttest processing time is 45 minutes.

Because at this meeting a posttest was held, students tended to be calm, not busy alone, not active, less happy and less enthusiastic. But the class atmosphere remains conducive so that the posttest process runs smoothly. At this meeting no material was presented and there was no use of PowerPoint media so that there was also no damage to the media. Student involvement and cooperation between students and teachers are good. One person was absent due to illness. All of this is summarized in the field notes of cycle I meeting II.

\section{Analysis of Learning Outcomes Cycle I}

The posttest results from fourth grade students using thematic learning materials using power point media with a total of 20 students can be seen in table 1 below:

Table 1. Percentage of Completeness of Student Learning Outcomes in Cycle I

\begin{tabular}{llrl} 
Minimum Completeness & Completed $(\geq 75)$ & $90 \%$ & 16 people \\
\cline { 2 - 4 } Standard: 75 & Inomplete $(<75)$ & $10 \%$ & 4 people \\
\hline & Total & $100 \%$ & 20 people \\
\hline
\end{tabular}

Based on the analysis of learning outcomes in the first cycle, it is known from the 20 students who took the posttest, there were 16 students who got a score of 75 with a learning completeness of $90 \%$. While students who get a value of $<75$ with a learning completeness of $10 \%$ there are 4 people.

\section{Action Reflection Cycle I}

Based on the results of observations and field notes, it is known that in the first cycle there are still some shortcomings, namely:

a. There were 2 students who were joking when the researcher explained the material so that these students did not pay attention to the lesson.

b. Researchers are too fast in conveying the material.

From the results of this reflection, several corrective actions were taken:

a. Forbid students to joke with their friends during the lesson.

b. More often provide feedback to students so that students better understand the subject matter presented.

c. Slow down the speed of speech when delivering material.

\section{B. Teaching and Learning Activities Cycle II}

1. Cycle II Action Planning Stage

As in the first cycle, before the implementation stage, in the second cycle, several preparations will be made as follows: 
a. Develop a Learning Implementation Plan (RPP) for cycle II.

b. Prepare relevant books.

c. Arrange material.

d. Arrange questions posttest for cycle II.

e. Compile a field note sheet for the cycle.

\section{Cycle II Action Implementation Stage}

The implementation of learning in cycle II was carried out for $2 \times 45$ minutes ( 2 hours of lessons) which was divided into 2 meetings.

\section{a. Meeting I}

At the first meeting, teaching and learning activities began by saying greetings, praying, attending to students and slightly repeating the material that had been discussed at the previous meeting for 3 minutes. When the first slide is projected on the screen, the teacher provides an illustration of the thematic learning materials that will be discussed at this meeting for two minutes. For forty minutes, the core learning activity begins with the second slide, the teacher explains the thematic learning materials using PowerPoint learning media with the lecture method for 40 minutes including giving feedback to students.

Based on the data from the field notes of the second cycle of the first meeting, it was found that during the teaching and learning activities the students looked calmer, more active, happy, and more enthusiastic than in the first cycle. The class atmosphere was conducive so as to support the smooth teaching and learning activities. All materials in the Learning Implementation Plan (RPP) have been delivered to students and there is no damage to the Microsoft PowerPoint media. Student involvement and cooperation between students and teachers are good.

\section{b. Meeting II}

During the second meeting, students were given a posttest of thematic learning. In this posttest, each student gets one question, one answer sheet, and one questionnaire which is done independently and there is no cooperation in any form. Posttest processing time is 45 minutes.

Field notes, showed that at this meeting the students were calm, not busy alone, not active, less happy and less enthusiastic. The class atmosphere is conducive so that it supports the posttest process. Because at this meeting a posttest was held, so no material was delivered using PowerPoint media. Student involvement and cooperation between students and teachers are good.

\section{Analysis of Learning Outcomes Cycle II}

The posttest results of the thematic learning materials can be seen in table 2 below:

Tabel 2. Persentase Ketuntasan Hasil Belajar Siswa Pada Siklus II

\begin{tabular}{clcc}
\hline \multirow{2}{*}{ Minimum Completeness Standard: 75} & Completed $(\geq 75)$ & $95 \%$ & 38 people \\
\cline { 2 - 4 } & Incomplete $(<75)$ & $5 \%$ & 2 people \\
\hline & Tota; & $100 \%$ & 40 people \\
\hline
\end{tabular}

Based on the analysis of learning outcomes in cycle II, it is known that from the 20 students who took the posttest, 18 students who got a score of 75 with learning completeness of $95 \%$ were 18 people. While students who get a value of $<75$ with a learning completeness of $5 \%$ there are as many as 2 people. 


\section{Action Reflection Cycle II}

The implementation of corrective actions from cycle I resulted in cycle II, namely:

a. There were no students joking with their friends when the researcher explained the material.

b. There are more students who ask the researchers about the material that has not been understood as seen from the increase in student learning outcomes in cycle II

\section{Student Response to the Application of Microsoft PowerPoint Media in Teaching and Learning Activities}

Students' responses to the application of Microsoft PowerPoint media in teaching and learning activities are known from a questionnaire with 10 questions distributed at the end of the posttest in cycle II. Based on the results of the questionnaire analysis, the first question shows that students enjoy learning by using PowerPoint media. The result of percentage calculation for answer Y (yes) is $77.5 \%, \mathrm{KD}$ (sometimes) is $22.5 \%$, and no student chooses answer $\mathrm{T}$ (no).

The second question shows that students agree that the Power-Point media makes it easier to understand the Request for Quotation material explained. It is evident from the results of the percentage calculation for the answer Y (yes) is $62.5 \%$, $\mathrm{KD}$ (sometimes) is $35 \%$, and $\mathrm{T}$ (no) is $2.5 \%$.

The third question, students agree that teaching and learning activities become more fun when using PowerPoint media, as evidenced by the calculation of the percentage of the third question where for the answer Y (yes) is 65\%, KD (sometimes) is $32.5 \%$, and $\mathrm{T}$ (no) by $2.5 \%$.

The fourth question, as many as $50 \%$ of students think that through learning with PowerPoint media, it makes them more daring to express their opinions, $37.5 \%$ of students think that it only happens occasionally. While students who do not agree as much as $12.5 \%$.

The fifth question shows that learning by using PowerPoint media can improve student learning outcomes. It is evident from the results of the percentage calculation for the answer $\mathrm{Y}$ (yes) is $62.5 \%, \mathrm{KD}$ (sometimes) is $27.5 \%$, and $\mathrm{T}$ (no) is $10 \%$.

The sixth question, as many as $62.5 \%$ of students do not feel bored during learning with PowerPoint media. Students who sometimes feel bored are $32.5 \%$ and $5 \%$ of students feel bored during learning with PowerPoint media.

The seventh question, as many as 55\% of students prefer learning who use PowerPoint media rather than learning that uses the blackboard and chalk. A total of $37.5 \%$ of students answered KD (sometimes) only, and $7.5 \%$ of students who liked learning using the blackboard and chalk.

The eighth question, as many as $70 \%$ of students who always pay attention to the teacher's explanation when economics lessons take place if the teacher uses PowerPoint media, $25 \%$ of students only pay attention sometimes, and there are $5 \%$ of students who do not pay attention to the teacher at all.

The ninth question, students who agree that students can concentrate more on economics lessons if they use PowerPoint as much as $62.5 \%$, sometimes only $25 \%$, and not as much as $12.5 \%$.

The tenth question, as many as $57.5 \%$ of students, believes that learning using PowerPoint media needs to be applied to other subjects. Students who think PowerPoint media are only occasionally as much as $30 \%$. While those who answered did not need as many as $12.5 \%$ of students. 


\section{Discussion}

\section{Application of Power Point Media to the Thematic Learning of Class IV Students at SDN Kemuning}

The application of PowerPoint media to thematic learning of fourth grade students is proven to improve student learning outcomes from the cognitive aspect because PowerPoint media has been designed in such a way according to the principle of selecting learning media so that it becomes a good learning media. The principles of media selection that have been met are:

a. Suitability

PowerPoint media is designed according to thematic learning materials. In the material there are various kinds of discussions that need to be explained to students, so that on the slides in this media the material is well described, given various colors and supported by appropriate animations to make it easier for the teacher to explain the curves.

b. Degree of difficulty

The level of language difficulty used and the discussion of the material on each slide in PowerPoint media has been adjusted to the thinking skills of fourth grade students. This adjustment is based on the books used by teachers and students.

c. Technical quality

The quality of Microsoft PowerPoint media is very good because this media has several facilities at once that other media do not have. Microsoft PowerPoint has many characters and font sizes, various colors, and a variety of animation options so that students will more easily grasp the material presented by the teacher.

d. Proven useful for students

The increase in learning outcomes from the cognitive aspects of students in this study has proven that PowerPoint is useful for students.

e. Provide stimulation / stimulation to learn

Microsoft Power Point is made in such a way by combining various colors, sizes and shapes of letters, and various animations so that students are interested in the material presented so that students want to learn.

f. Activate student response.

Because the Microsoft PowerPoint media is made in simple language, students can conclude for themselves the material presented in the slides that have been made so that students not only listen to the teacher's explanations but also actively ask questions.

g. Provide variety in teaching because communication between teachers and students is not only verbal

Communication between teachers and students can be established not only verbally but also through writing on Microsoft PowerPoint slides so that communication can be established even better.

h. Make it easier for teachers to provide material to students who have different levels of understanding.

Each student has different abilities in understanding a material. There are students who respond quickly to the new material presented, there are also students who need to be guided repeatedly to be able to understand the new material. To bridge it, teachers can use media so that no students are left behind in understanding a material.

\section{Class IV Student Learning Outcomes After Power Point Media Applied in Thematic Learning at SDN Kemuning}

Learning outcomes are defined as student achievement of the learning objectives 


\section{Dian Nur Antika Eky Hastuti}

that have been set which are marked by changes in student behavior, both from the cognitive, affective, and psychomotor aspects. Comparison of learning outcomes between cycle I and cycle II can be seen in the following table:

Table 3. Comparison of Student Learning Outcomes

\begin{tabular}{|c|c|c|c|c|}
\hline & \multicolumn{4}{|c|}{ Minimum Completeness Standard $=75$} \\
\hline & \multicolumn{2}{|c|}{ Cycle I } & \multicolumn{2}{|c|}{ Cycle II } \\
\hline & $\sum$ & $\%$ & $\sum$ & $\%$ \\
\hline $\begin{array}{l}\text { Completed } \quad \text { (Minimum } \\
\text { Completeness Standard } \geq 75)\end{array}$ & 16 & $90 \%$ & 18 & $95 \%$ \\
\hline $\begin{array}{l}\text { Incomplete } \quad \text { (Minimum } \\
\text { Completeness Standard < 75) }\end{array}$ & 4 & $10 \%$ & 2 & $5 \%$ \\
\hline $\begin{array}{l}\text { Students whose grades have } \\
\text { increased }\end{array}$ & - & - & 14 & $65 \%$ \\
\hline Students whose grades dropped & - & - & 3 & $17,5 \%$ \\
\hline Fixed grade students & - & 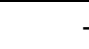 & 3 & $17,5 \%$ \\
\hline
\end{tabular}

Because this study limits students' changes in cognitive aspects only, according to the Subject Teacher Consultation (MGMP) and school standards, the Minimum Completeness Standard (SKM) is 75 for thematic subjects of class IV. In the comparison table of student learning outcomes, in the first cycle it can be seen that in the thematic learning posttest of 20 students who following the posttest, 16 students who got a score of 75 with a learning completeness of $90 \%$. While students who get a value of $<75$ with a learning completeness of $10 \%$ are 4 people.

Students who do not complete are indicated to have problems with their physical condition, such as students with absent number 6 , who are absent during the posttest and do not come during the follow-up exam so that they get a minimum score.

In the comparison table of student learning outcomes, in the second cycle it can be seen that, from the thematic learning posttest of 20 students who took the posttest, the number of students who got a score of 75 with learning completeness was $95 \%$ as many as 18 people. While students who get a value of $<75$ with a learning completeness of $5 \%$ there are 2 people.

From table 3 Comparison of student learning outcomes, it can be stated that the posttest average value and the percentage of learning completeness from cycle I to cycle II increased by 5\% where in cycle I the percentage of completeness was $90 \%$ and then increased to $95 \%$ in cycle II. In table 5.1 it is also known that as many as 14 students experienced an increase in grades in cycle II, while there were 3 students who experienced a decrease in grades. There were 3 students whose scores did not change in cycle II.

With this, it can be stated that there is a significant increase in student learning outcomes in cycle II when compared to student learning outcomes in cycle I.

\section{Responses of Class IV Students to the Application of Power Point Media in Thematic Learning at SDN Kemuning}

From the questionnaire analysis, it is known that students enjoy learning Economics by using PowerPoint media instead of using chalk and blackboard because through learning using PowerPoint media, students feel that teaching and learning activities are more fun, not boring, the material is clearer, easier to understand. That way students can concentrate more on paying attention to the teacher and expressing opinions so that teaching and learning activities using PowerPoint media can improve student learning outcomes. A total of 13 students agreed that PowerPoint should be applied to 
other grade levels.

There are also some students who do not like teaching and learning activities that use Microsoft PowerPoint media because it is difficult to understand the material, teaching 


\section{Dian Nur Antika Eky Hastuti}

and learning activities are felt to be uncomfortable, boring, so that some of these students cannot concentrate on paying attention to the teacher, these students also do not dare to express their opinions. All of these things resulted in learning outcomes did not increase. So that some of these students think that PowerPoint media does not need to be applied to other subjects.

\section{CONCLUSION}

Based on the results of the research and discussion that have been described previously, it can be concluded that the application of PowerPoint media to the thematic learning of fourth grade students at SDN Kemuning is proven to improve student learning outcomes from the cognitive aspect because Microsoft PowerPoint media has been designed in such a way according to the principle of selecting learning media. so that it becomes a good learning media. The application of PowerPoint media is proven to improve learning outcomes in thematic learning of fourth grade students at SDN Kemuning. This is indicated by the average value of the post test and the percentage of mastery learning from cycle I to cycle II which increased by $5 \%$.

Based on the questionnaire analysis containing student responses to the application of PowerPoint media in the thematic learning of fourth grade students at SDN Kemuning, it shows that students are happy with the application of Power Point media and through the application of Microsoft PowerPoint media students can more easily understand the material presented by the teacher. Based on the conclusions above, it can be said that there is a significant effect on learning outcomes with the application of Power Point media with the lecture method on thematic learning as evidenced by the learning mastery of fourth grade students at SDN Kemuning.

\section{REFERENCES}

Abi Hamid, Mustofa, Ramadhani, Rahmi, Masrul, Masrul, Juliana, Juliana, Safitri, Meilani, Munsarif, Muhammad, Jamaludin, Jamaludin, \& Simarmata, Janner. (2020). Media pembelajaran. Yayasan Kita Menulis.

Bici, La Ode. (2020). PENGEMBANGAN MEDIA PEMBELAJARAN ARITMATIKA SOSIAL MELALUI GAME BERBASIS POWER POINT. Universitas Muhammadiyah Malang.

Djamarah, Syaiful Bahri, \& Zain, Aswan. (2006). Strategi Belajar Mengajar. Jakarta: PT Rineka Cipta. Syaiful Bahri Djamarah Dan Aswan Zain.

Efendi, Mohammad. (2009). Kurikulum dan pembelajaran: pengantar ke arah pemahaman KBK, KTSP, dan SBI. Malang: Universitas Negeri Malang.

Fandana, Desti Alifia, \& Indrianti, Deditiani Tri. (n.d.). Efektivitas Penerapan Media Power Point Terhadap Pembelajaran Sejarah Warga Belajar Kelas XI Paket C Di SKB Bondowoso Semester Genap Tahun Pelajaran 2012-2013.

Hermawansyah, Hermawansyah. (2021). Manajemen Lembaga Pendidikan Sekolah Berbasis Digitalisasi Di Era Covid-19. Fitrah: Jurnal Studi Pendidikan, 12(1), 2746.

Kustiawan, Usep. (2016). Pengembangan media pembelajaran anak usia dini. Penerbit Gunung Samudera [Grup Penerbit PT Book Mart Indonesia].

Misbahudin, Dede, Rochman, Chaerul, Nasrudin, Dindin, \& Solihati, Isoh. (2018). Penggunaan Power Point Sebagai Media Pembelajaran: Efektifkah? WaPFi (Wahana Pendidikan Fisika), 3(1), 43-48.

Nurseto, Tejo. (2011). Membuat media pembelajaran yang menarik. Jurnal Ekonomi Dan Pendidikan, 8(1). 
Prastowo, Andi. (2014). Pemenuhan kebutuhan psikologis peserta didik SD/MI melalui pembelajaran tematik-terpadu. Jurnal Pendidikan Sekolah Dasar Ahmad Dahlan, $1(1), 1-13$.

Rosyidah, Alfin Kholifatur. (2015). Problematika pembelajaran tematik integratif kelas IV Sekolah Dasar Negeri Tumpang 01 Kabupaten Malang. Universitas Islam Negeri Maulana Malik Ibrahim.

Sadiman, Arief S., Rahardjo, Rahardjito, \& Haryono, Anung. (2003). Media pendidikan: pengertian, pengembangan dan pemanfaatannya.

Suratman, Dede. (2009). Pemanfaatan Ms Power Point dalam Pembelajaran. Jurnal Cakrawala Kependidikan, 7(1).

Wahyuni, Hermin Tri, Setyosari, Punaji, \& Kuswandi, Dedi. (2017). Implementasi pembelajaran tematik kelas 1 SD. Edcomtech Jurnal Kajian Teknologi Pendidikan, 1(2), 129-136.

Wanti, Estu Zunia. (n.d.). Improvement of Counting Abilities Through the Powerpoint Media in Elementary School Grade II. Social, Humanities, and Educational Studies (SHEs): Conference Series, 3(3), 93-100. 